\title{
PERBEDAAN FREKUENSI MIKSI, DEFEKASI, DAN MINUM DENGAN PENURUNAN BERAT BADAN NEONATUS DI WILAYAH KERJA PUSKESMAS BANDA SAKTI
}

\author{
Mauliza $^{1}$, Noviana Zara ${ }^{2}$, Narisha Amelia Putri ${ }^{3}$ \\ ${ }^{1)}$ Ilmu Kesehatan Anak, Fakultas Kedokteran, Universitas Malikussaleh, Lhokseumawe \\ ${ }^{2)}$ Ilmu Kesehatan Masyarakat, Fakultas Kedokteran, Universitas Malikussaleh, Lhokseumawe \\ ${ }^{3)}$ Mahasiswa Fakultas Kedokteran, Universitas Malikussaleh, Lhokseumawe \\ Corresponding Author : narisha.160610030@mhs.unimal.ac.id
}

\begin{abstract}
Abstrak
Neonatus memiliki peran penting untuk tumbuh kembang anak. Neonatus memiliki komposisi air sekitar $75 \%$ yang akan berkurang dalam minggu pertama karena terjadi pergeseran cairan dari intraseluler ke ekstraseluler. Proses kehilangan cairan dipengaruhui oleh frekuensi miksi, defekasi, dan minum sehingga mengakibatkan terjadinya penurunan berat badan neonatus $\geq 5 \%$. Menurut penelitian Mezzacappa 2016 didapatkan data neonatus sebanyak 25,8\% yang mengalami penurunan berat badan berlebih yaitu sekitar $9,4 \% \pm 1,1 \%$, dan didapatkan neonatus yang mengalami penurunan lebih dari $10 \%$ yaitu sebanyak $4,8 \%$ neonatus. Penelitian ini bertujuan untuk mengetahui perbedaan frekuensi miksi, defekasi, dan minum terhadap penurunan berat badan neonatus di wilayah kerja Puskesmas Banda Sakti dengan melibatkan 57 orang neonatus mulai dari usia $0-7$ hari menggunakan rancangan survei prospektif serta metode kohort (longitudinal study). Hasil analisis univariat didapatkan frekuensi miksi, defekasi, minum dan penurunan berat badan neonatus dalam batas normal. Hasil analisis bivariat menggunakan uji Chi-square dan alternatifnya dengan mempertimbangkan nilai $\mathrm{p}<0.05$ menunjukkan terdapat perbedaan antara frekuensi miksi dan penurunan berat badan $[(\mathrm{P}=0.005),(\mathrm{OR}=8.105),(95 \% \mathrm{CI}=1.630-40.295)]$; terdapat perbedaan antara frekuensi defekasi dan penurunan berat badan $[(\mathrm{P}=0.026), \quad(\mathrm{OR}=3.600)$, $(95 \% \mathrm{CI}=1.140-11.373)]$; tidak terdapat perbedaan antara frekuensi minum dan penurunan berat badan [total $(\mathrm{P}=0.291), \quad(\mathrm{OR}=3.172), \quad(95 \% \mathrm{CI}=0.332-30.359)]$; $\quad$ [ASI $\quad(\mathrm{P}=0.808)$, $(\mathrm{OR}=1.150),(95 \% \mathrm{CI}=0.372-3.551)$ ]; [ susu formula $(\mathrm{P}=0.415),(\mathrm{OR}=1.474),(95 \% \mathrm{CI}=0.375$ 5.797)]. Kesimpulan penelitian adalah terdapat perbedaan antara frekuensi miksi dan defekasi dengan penurunan berat badan neonatus, tetapi tidak terdapat perbedaan antara frekuensi minum dengan penurunan berat badan neonatus.
\end{abstract}

Kata Kunci $\quad$ : berat badan; defekasi; miksi; minum 


\title{
Differences Between Frequency Of Micturition, Defecation, And Drink With Neonatal Weight Loss In The Work Area Of Banda Sakti Health Center
}

\begin{abstract}
The neonatal period is an important phase in a child's growth and development. Neonate has a body water composition of around $75 \%$. Excessive body water composition will gradually decrease in the first week due to the shift of fluid from intracellular to extracellular and trigger fluid loss in the body. The process of fluid loss is influenced by micturition, defecation, and drink will affect neonatal weight loss of around $\geq 5 \%$. Mezzacappa on 2016 get 25,8\% neonates has weight loss $9,4 \% \pm 1,1 \%$, ans neonates has weight loss more than $10 \%$ on $4,8 \%$. This study aims to determine the differences between the frequency of micturition, defecation, and drink with neonatal weight loss in the work area of Banda Sakti Health Center with involved 57 neonates from the age of 0-7 days and use longitudinal study (cohort method) and prospective study design. Univariate analysis gets normal frequency of micturition, defecation, drink and weight loss of neonates. Bivariate analysis with Chi-square test and the alternatives focus to $\mathrm{p}<0.05$ showing there is a difference between frequency of micturition and weight loss $[(\mathrm{P}=0.005),(\mathrm{OR}=8.105),(95 \% \mathrm{CI}=1.630$ to 40.295$)]$; there is a difference between frequency of defecation and weight loss $[(\mathrm{P}=0.026),(\mathrm{OR}=3.600),(95 \% \mathrm{CI}=1.140$ to 11.373)]; there is no difference between frequency of drink and weight loss [total $(\mathrm{P}=0.291)$, $(\mathrm{OR}=3.172),(95 \% \mathrm{CI}=0.332$ to 30.359$)$ ]; [breast $(\mathrm{P}=0.808),(\mathrm{OR}=1.150),(95 \% \mathrm{CI}=0.372$ to 3.551)]; [formula $(\mathrm{P}=0.415),(\mathrm{OR}=1.474),(95 \% \mathrm{CI}=0.375$ to 5.797$)]$. The conclusion of this study is that there is a difference between the frequency of micturition and defecation with neonatal weight loss, but there is no difference between the frequency of drink with neonatal weight loss.
\end{abstract}

Keywords: defecation; drink; micturition; weight loss

\section{PENDAHULUAN}

Neonatus merupakan suatu periode berkenaan dengan 4 minggu pertama kelahiran yang sangat rawan bagi bayi dikarenakan terjadi perubahan kondisi fisiologis tubuh dan berperan penting untuk bertahan hidup serta tumbuh kembang dikemudian hari $(1,2)$. Perubahan yang terjadi salah satunya adalah penurunan berat badan sekitar 5\% bahkan lebih (3).

Penelitian Mezzacappa tahun 2016 mendapatkan hasil rata-rata penurunan berat badan pada neonatus sekitar $6,44 \pm 2,5 \%$. 25,8\% mengalami penurunan berat badan yang berlebih dengan rata-rata penurunan berat badan sekitar $9,4 \% \pm 1,1 \%$, bahkan pada $4,8 \%$ neonatus terjadi penurunan berat badan yang sangat signifikan yaitu lebih dari 10\% (4).

Berat badan merupakan penghitungan rerata dari status nutrisi secara umum (5). Berat badan lahir normal berkisar $\geq 2500-4000$ gram. Berat badan pada neonatus dipengaruhi oleh komposisi air yang ada didalam tubuh (6). Komposisi air pada neonatus lebih tinggi sekitar 90\% dari berat badan (7). Komposisi air yang berlebih akan berangsur-angsur kurang dalam 
minggu pertama kelahiran, hal ini dapat dilihat melalui penurunan berat badan sekitar 5\% bahkan lebih (8). Timbunan cairan pada ekstraseluler akan memicu proses diuresis pada 48 sampai 72 jam setelah kelahiran (9).

Proses diuresis menghasilkan kontraksi isotonik ruang ekstraseluler, natrium negatif sementara dan keseimbangan air. Keseimbangan air akan dicapai melalui perawatan pemeliharaan cairan berupa pertimbangan matabolisme oksidatif ditambah IWL (Invisible Water Loss) dan hilangnya air dalam proses miksi dan defekasi $(10,11)$

IWL adalah suatu proses kehilangan air yang tidak mudah diukur, sebagian besar terdiri dari air yang hilang melalui penguapan berupa kulit (2/3) atau saluran pernapasan (1/3) (8). IWL pada neonatus sekitar $20 \mathrm{ml} / \mathrm{kg} /$ hari atau 0,7-1,6 ml/kg/jam (10). Kehilangan cairan selanjutnya melalui proses miksi dan defekasi (2). Kehilangan cairan melalui miksi melalui proses ekskresi ginjal yang berakhir dengan produksi urin sekitar 56\% dari total kebutuhan air tubuh yaitu 50-100 ml/kg/hari, hal ini dikarenakan neonatus akan miksi 5-6 kali bahkan lebih dalam sehari $(10,12)$.

Kehilangan cairan melalui defekasi ialah proses kehilangan cairan melalui proses pencernaan yang berakhir dalam produksi tinja. Neonatus akan defekasi 3-4 kali per hari bahkan lebih (12). Kehilangan cairan melalui tinja berkisar sekitar 5\% dari total kehilangan cairan tubuh. Kehilangan cairan yang bermakna melalui proses pergeseran kompartemen cairan terutama pada proses miksi dan defekasi akan mempengaruhi penurunan berat badan neonatus (10).

Komposisi cairan didalam tubuh neonatus juga dipengaruhi oleh frekuensi minum yaitu berupa asupan yang diterima oleh neonatus. Asupan berupa ASI akan mengakibatkan terjadinya peningkatan gastric inhibitor polypeptide, motilin, neurotensin, dan vasoactive intestinal peptide. Hal ini akan mengakibatkan terjadinya peningkatan pembuangan cairan didalam tubuh neonatus tersebut yang secara tidak langsung akan mengurangi dari berat badan neonatus (13). Asupan minum berupa susu formula akan mempengaruhi berat badan yang berbeda. Hal ini dikarenakan kandungan yang terdapat didalam susu formula mengakibatkan terjadinya kelebihan retensi air dan komposisi lemak tubuh (14).

\section{METODELOGI PENELITIAN}

Penelitian ini menggunakan jenis design penelitian kohort dan rancangan survei prospektif dengan pendekatan longitudinal. Penelitian ini dilakukan di wilayah kerja Puskesmas Banda Sakti. Populasi pada penelitian ini adalah seluruh neonatus di wilayah kerja Puskesmas Banda Sakti yang lahir dalam kondisi sehat. Sampel pada penelitian ini adalah 
sebagian neonatus yang memenuhi kriteria inklusi dan eksklusi. Kriteria inklusinya adalah : 1) Bayi usia 0-7 hari, 2) Bayi lahir cukup bulan atau lebih, 3) Bayi lahir spontan, 4) Lahir sehat dan tidak memiliki kelainan kongenital, 5) Selama penelitian bayi hanya menggunakan popok kain. Kriteria eksklusinya adalah : BBLR dan lahir kurang bulan. Besar sampel minimal yang diteliti sebanyak 57 neonatus. Sampel akan dipilih dengan menggunakan teknik Non Probability Sample dengan cara Accidental Sampling. Analisis dan pengajian data menggunakan analisis univariat dan analisis bivariat menggunakan uji chi-square dan alternatifnya.

\section{HASIL PENELITIAN}

1. Analisis Univariat

Karakteristik responden terdiri dari : jenis kelamin laki-laki (54.4\%). Panjang badan $48.00 \mathrm{~cm}$ (28.1\%). Lingkar kepala $35.00 \mathrm{~cm}$ (31.6\%). Skor APGAR menit pertama yaitu 10 (52.6\%). Usia ayah yaitu 26-35 tahun (59.6\%). Usia ibu responden yaitu 26-35 tahun (64.9\%). Urutan kelahiran yaitu urutan pertama (42.1\%).

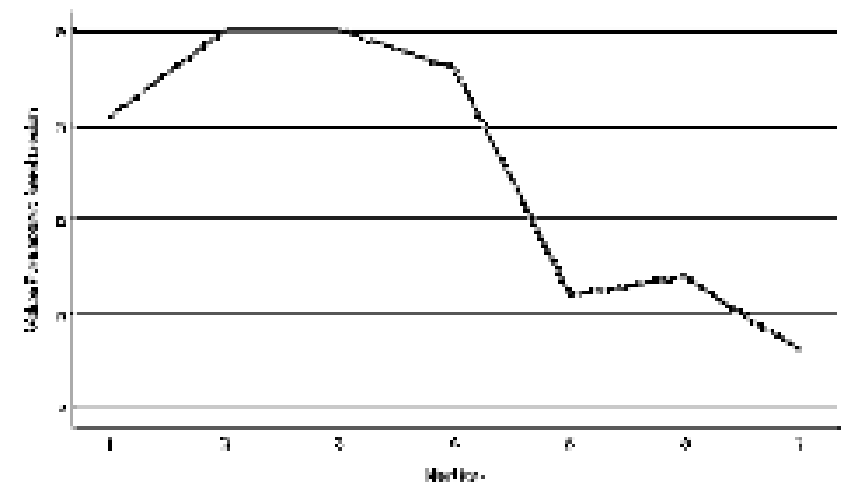

Gambar 1 Sebaran penurunan berat badan

Berdasarkan gambar 1 didapatkan bahwa responden yang mengalami penurunan berat badan terbanyak yaitu pada hari kedua dan ketiga (70.2\%). Berdasarkan gambar 2 didapatkan bahwa distribusi frekuensi miksi normal terbanyak yaitu pada hari ketiga $(87.7 \%)$. Berdasarkan gambar 3 didapatkan bahwa distribusi frekuensi defekasi normal terbanyak yaitu pada hari pertama $(86.0 \%)$. 


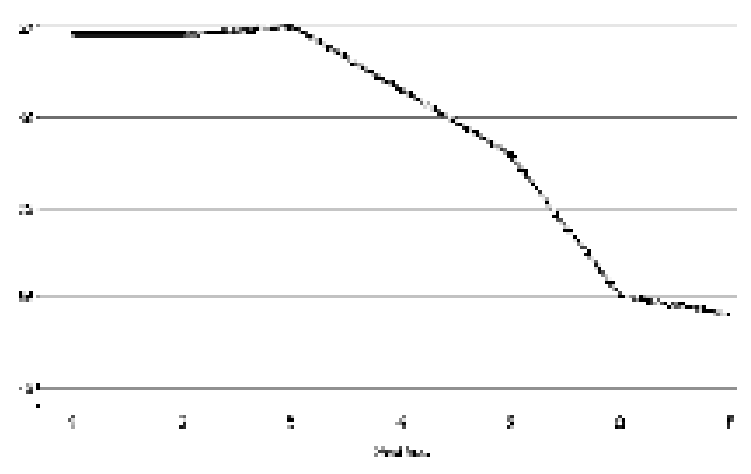

Gambar 2 Sebaran frekuensi miksi normal

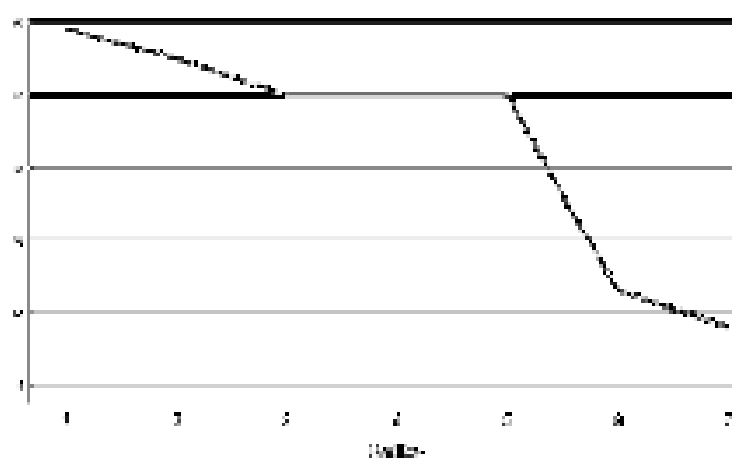

Gambar 3 Sebaran frekuensi defekasi normal

Distribusi frekuensi minum pada responden terbagi menjadi : minum total, ASI, dan susu formula. Frekuensi minum normal terbanyak yaitu pada hari pertama dengan jumlah (96.5\%). Frekuensi minum ASI normal terbanyak yaitu pada hari keempat (59.6\%). Frekuensi minum susu formula normal terbanyak yaitu pada hari pertama dan kedua (24.6\%).

2. Analisis Bivariat

a. Perbedaan frekuensi miksi dengan penurunan berat badan neonatus

Tabel 1 Perbedaan frekuensi miksi dengan penurunan berat badan

\begin{tabular}{|c|c|c|c|c|c|c|c|c|c|c|c|}
\hline \multirow{3}{*}{\multicolumn{2}{|c|}{ Kategori }} & \multicolumn{6}{|c|}{ Penurunan Berat Badan } & \multirow{3}{*}{ Nilai p } & \multirow{2}{*}{\multicolumn{3}{|c|}{ Nilai OR }} \\
\hline & & \multicolumn{2}{|c|}{$\mathrm{Ya}$} & \multicolumn{2}{|c|}{ Tidak } & \multicolumn{2}{|c|}{ Total } & & & & \\
\hline & & $\mathrm{n}$ & $\%$ & $\mathrm{n}$ & $\%$ & $\mathrm{~N}$ & $\%$ & & Value & Lower & Upper \\
\hline \multirow{3}{*}{$\begin{array}{l}\text { Frekuensi } \\
\text { Miksi }\end{array}$} & Normal & 22 & 53.7 & 19 & 46.3 & 41 & 100 & \multirow{3}{*}{0.005} & \multirow{3}{*}{8.105} & \multirow{3}{*}{1.630} & \multirow{3}{*}{40.295} \\
\hline & Kurang & 2 & 12.5 & 24 & 87.5 & 16 & 100 & & & & \\
\hline & Total & 24 & 42.1 & 33 & 57.9 & 57 & 100 & & & & \\
\hline
\end{tabular}

Analisis bivariat perbedaan frekuensi miksi dengan penurunan berat badan menggunakan uji chi-square didapatkan $\mathrm{P}$ value sebesar 0.005 yang berarti Ha diterima $(\alpha<0.05)$. Nilai Odds ratio 8.105 selang kepercayaan [(1.630),(40.295)].

b. Perbedaan frekuensi defekasi dengan penurunan berat badan neonatus

Tabel 2 Perbedaan frekuensi defekasi dengan penurunan berat badan

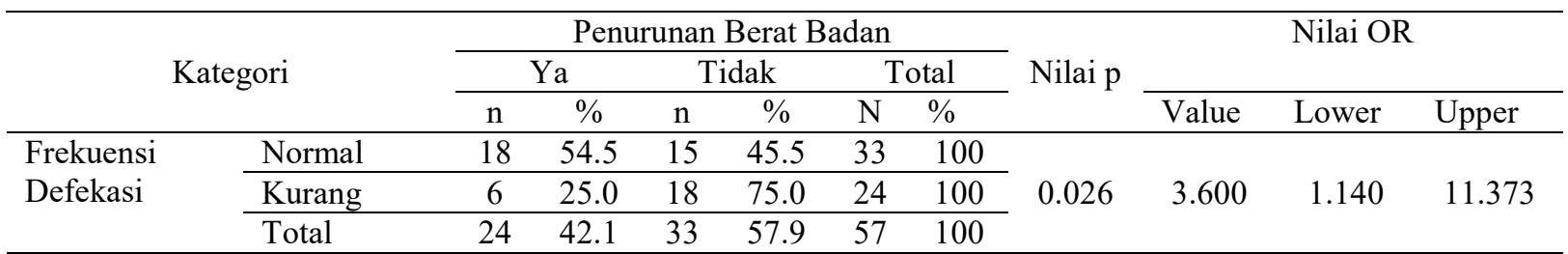

Tabel 2 menunjukkan analisis bivariat frekuensi defekasi dengan penurunan berat badan menggunakan uji chi-square didapatkan $\mathrm{P}$ value sebesar 0.026 yang berarti Ha diterima $(\alpha<0.05)$, Nilai Odds ratio 3.6 selang kepercayaan [(1.140),(11.373)]. 
c. Perbedaan frekuensi minum dengan penurunan berat badan neonatus

Hasil analisis bivariat perbedaan frekuensi minum total dengan penurunan berat badan, uji fisher didapatkan nilai P value 0.29 yang berarti Ho diterima $(\alpha>0.05)$. Nilai Odds ratio 3.17 selang kepercayaan [(0.332),(30.359)]. Analisis bivariat uji chi-square mengenai perbedaan frekuensi ASI dengan penurunan berat badan didapatkan nilai $\mathrm{P}$ value sebesar 0.808 yang berarti Ho diterima $(\alpha>0.05)$. Nilai Odds ratio 1.15 dengan selang kepercayaan [(0.372),(3.551)]. Analisis bivariat menggunakan uji fisher mengenai perbedaan frekuensi susu formula dengan penurunan berat badan didapatkan nilai signifikansi P value sebesar 0.415 yang berarti Ho diterima $(\alpha>0.05)$. Nilai Odds ratio 1.47 dengan selang kepercayaan $[(0.375),(5.797)]$.

\section{PEMBAHASAN}

\section{Analisis Univariat}

Berat badan neonatus mengalami penurunan selama hari-hari pertama kelahirannya. Penurunan berat badan neonatus pada umumnya terjadi sekitar 5-10\% akibat penyesuaian diri dengan dunia luar. Berat badan neonatus akan kembali pada berat badan lahir semula pada minggu kedua kehidupan (6). Rata-rata persentase penurunan berat badan untuk neonatus adalah $4,2 \%, 7,1 \%$, dan 6,4\% pada usia 24, 48, 72 jam. Neonatus usia 48 jam, hampir 5\% bayi baru lahir yang dilahirkan telah kehilangan setidaknya $10 \%$ dari berat lahir. Penurunan berat badan akan mencapai puncaknya pada hari ketiga kelahiran $(15,16)$. Joshi pada tahun 2017 mendapatkan hasil yang sama mengenai penurunan berat badan yaitu sekitar 79.2\% neonatus kehilangan 5-10\% dari berat lahir dan 12.8\% nenatus kehilangan lebih dari 10\%. Penurunan berat badan maksimum terjadi antara 60-72 jam kehidupan (17).

Frekuensi miksi yang tinggi pada neonatus disebabkan oleh nervus parasimpatik belum mampu mengatur pengisian vesica urinaria dengan baik, sehingga kontraksi otot akan terus terjadi. Proses kontraksi otot detrusor dan relaksasi otot sphinteric yang tidak terkoordinasi menyebabkan vesica urinaria yang belum penuh akan tetap mengeluarkan urin dalam jumlah yang sedikit. Proses pematangan organ sistem urogenital akan terjadi hingga mencapai usia 1 tahun $(18,19)$. Frekuensi miksi akan menurun sekitar 4-7 kali perharinya (20).

Frekuensi miksi akan mencapai puncak pada hari ketiga. Sejalan dengan penelitian Gladh tahun 2000, pada 51 orang neonatus sehat, didapatkan peningkatan frekuensi miksi dan volume urin pada 4 jam pertama di hari ketiga, dengan uji nonparametrik didapatkan $\mathrm{P}$ value $<0.05(21)$. 
Neonatus mempunyai aktivitas laktase yang belum optimal sehingga kemampuan menghidrolisis laktosa sangat terbatas. Kemampuan yang terbatas menyebabkan peningkatan tekanan osmolaritas di dalam lumen usus halus yang mengakibatkan peningkatan frekuensi defekasi $(22,23)$. Selain itu, waktu transit intestinal juga meningkat seiring dengan bertambah umur bayi (24). Rerata frekuensi defekasi paling tinggi terdapat pada masa neonatus awal (3,16 kali perhari) kemudian berkurang secara bermakna seiring dengan peningkatan usia (25).

Elbakyan tahun 1994, bahwa 60\% neonatus akan penuh dengan dekefaksi (terjadinya defekasi dengan frekuensi tinggi) pada 8 jam pertama kehidupan, 91\% pada 16 jam, 98,5\% pada 24 jam dan hampir 100\% pada 48 jam (26). Frekuensi defekasi paling tinggi pada minggu pertama kemudian berkurang seiring dengan bertambahnya umur (27).

Neonatus mengalami masalah dalam asupan ASI. Hasil ini dikarenakan pada hari pertama hingga ketiga banyak ibu yang mengeluhkan produksi ASI yang kurang, bahkan tidak keluar sama sekali. Secara teori hari pertama hingga ketiga merupakan produksi kolostrum pada ibu dengan volume 150-300 ml/24 jam(28). Pengeluaran kolostrum dipengaruhi oleh jenis persalinan, paritas, isapan bayi segera setelah lahir, status nutrisi ibu, dan pemberian anastesi saat persalinan $(29,30)$. Keterlambatan pengeluaran ASI pada ibu dipengaruhi oleh jenis persalinan, umur, status gizi, paritas, dan pendidikan (31).

Hal ini sejalan dengan penelitian Dina tahun 2016 menunjukkan bahwa jumlah responden yang mengalami pengeluaran kolostrum cepat yaitu sebanyak 33 responden (47,1\%), 21 responden dengan persalinan normal dan 12 dengan persalinan SC, sebanyak 37 $(52,9 \%)$ ibu yang melahirkan mengeluarkan kolostrum dengan waktu lama (29). Usia Ibu yang $>30$ tahun secara signifikan dapat menyebabkan keterlambatan permulaan laktasi. Umur yang lebih tua memiliki faktor risiko intolerans terhadap karbohidrat selama kehamilan sehingga menyebabkan berat badan ibu cenderung meningkat $(29,31)$.

Ibu yang baru pertama kali melahirkan (anak pertama) seringkali menemukan masalah dalam memberikan ASI (32). Meningkatnya pemberian susu formula pada neonatus disebabkan kurangnya pengetahuan mengenai manfaat ASI, pendidikan yang rendah, agresifnya promosi susu formula, dukungan petugas kesehatan(33). Rahmiwati tahun 2016 mengetahui sebagian anak mulai diberikan susu formula pada usia 0-6 bulan (97,88\%) (34).

2. Analisis bivariat

Perbedaan frekuensi miksi terhadap penurunan berat badan dikarenakan komposisi air pada neonatus hampir 90\% dari berat badan pada usia 24 minggu janin (7). Komposisi air 
yang berlebih akan berangsur-angsur kurang dalam minggu pertama kelahiran, hal ini dapat dilihat melalui penurunan berat badan sekitar 5\% bahkan lebih (8).

Penelitian ini sejalan dengan Weiss tahun 2011, hasil analisis bivariat penurunan berat badan pada neonatus usia 24 jam pertama berhubungan dengan frekuensi output cairan (miksi) pada periode yang sama dengan nilai $\mathrm{p}<0.001$ (0.493 SD) (35). Urine output akan mempengaruhi penurunan berat neonatus pada 24 dan 48 jam pertama kelahiran (36). Hal ini berarti neonatus dengan frekuensi miksi tinggi berkemungkinan 1.74 atau 2 kali untuk mengalami penurunan berat badan berlebih (37).

Kadar cairan yang tinggi didalam tubuh neonatus mengakibatkan terjadi proses fisiologis tubuh untuk mengeluarkan cairan tersebut melalui proses pencernaan. Kehilangan cairan melalui tinja berkisar sekitar 5\% dari total kehilangan cairan tubuh. Kehilangan cairan yang bermakna terjadi melalui proses pergeseran kompartemen cairan tubuh (10).

Penelitian ini sejalan dengan Lemoh pada tahun 1979 yang dilakukan pada 55 bayi usia 3 hari hingga 2 tahun didapatkan rata-rata frekuensi defekasi bayi pada minggu pertama kehidupan sekitar 0.5-22 SD, dan berat tinja sekitar 0.5-48 gram, sehingga mengakibatkan terjadi penurunan berat badan sesuai dengan berat tinja pada bayi tersebut (38).

Hasil penelitian ini sejalan dengan penlitian yang dilakukan Haseli tahun 2017 yang mendapatkan hasil penurunan berat badan neonatus pada hari ke 3-5 sekitar $4.04 \pm 3.19 \%$. Hasil analisis multivariat menunjukkan bahwa terdapat hubungan penurunan berat badan dengan konsumsi ASI dan susu formula (OR=7.228, CI : 4.707-11.099) $(39,40)$.

Konsumsi ASI bersamaan susu formula dapat mempengaruhi pola penurunan berat badan pada neonatus. Kadar karbohidrat pada ASI tidak terlalu tinggi, sedangkan didalam susu formula terdapat kadar protein yang tinggi. Penelitian Soetningsih 2016 didapatkan kenaikan berat badan bayi yang mendapat cukup ASI pada minggu pertama yaitu antara 2002500 gram. Pemberian ASI pada bayi sebaiknya tidak dijadwalkan tetapi bayi disusui sesuai dengan permintaan bayi $(41,42)$

Perbedaan penurunan berat badan neonatus antara yang diberi ASI eksklusif dengan susu formula dapat disebabkan karena kandungan pemanis buatan yang terlalu banyak dalam susu formula yang banyak dijual di pasaran menyebabkan kenaikan berat badan sangat cepat pada bayi yang diberikan susu formula. (43). Konsumsi ASI yang bersamaan dengan susu formula dapat mempengaruhi pola penurunan berat badan pada neonatus. Hal ini dikarenakan sifat antara ASI dan susu formula yang berlawanan.

Hal ini sejalan dengan penelitian lain yang dilakukan oleh Yusuf tahun 2011 tentang pemberian Susu Formula diperoleh bahwa dari 47 orang ibu yang memiliki anak usia 7-11 
bulan yang berada dalam wilayah kerja Puskesmas Minasa Upa Makassar Tahun 2011, ibu yang yang memberi susu formula lebih banyak yakni 33 bayi (70,2\%) (44).

Dari hasil wawancara diperoleh rendahnya frekuensi ASI pada hari-hari pertama kelahiran dikarenakan keluhan ibu akan kurangnya produksi ASI, sehingga untuk memenuhi kecukupan nutrisi neonatus ibu menggantinya dengan penggunaan susu formulai. Ibu-ibu mengatakan bahwa alasan memberikan susu formula di karenakan lebih praktis dan mudah (kebanyakan ibu baru melahirkan di Banda Sakti tidur di ruang keluarga), alasan pemberian susu formula pada anak di disebabkan karena ASI yang tidak keluar dan iklan-iklan yang ada di TV ataupun media membuat para ibu tertarik untuk lebih memberikan susu formula pada anak mereka. Hal ini didukung dengan kurangnya sosialisasi dari bidan tempat melahirkan mengenai pentingnya pemberian ASI eksklusif. Bahkan pada beberapa klinik bersalin menyediakan susu formula bubuk di ruangan pasca persalinan (ruang inap).

\section{KESIMPULAN DAN SARAN}

Karakteristik dominan yaitu jenis kelamin laki-laki 54.4\%, panjang badan berkisar 45.00-53.00 cm, lingkar kepala berkisar 32-38.50 cm, skor APGAR menit pertama terbanyak yaitu 10 sebanyak 52.6\% dengan kategori normal 100\%, usia ayah dan ibu yaitu 26-35 tahun, dan urutan kelahiran pertama $42.1 \%$.

Neonatus yang mengalami penurunan berat badan terbanyak yaitu pada hari kedua dan ketiga 70.2\%. Frekuensi miksi normal terbanyak yaitu pada hari ketiga 87.7\% . Frekuensi defekasi normal terbanyak yaitu pada hari pertama $86.0 \%$. Frekuensi minum total normal terbanyak yaitu pada hari pertama dengan $96.5 \%$. Frekuensi minum ASI normal terbanyak yaitu pada hari keempat $59.6 \%$. Frekuensi minum susu formula normal terbanyak yaitu pada hari pertama dan kedua $24.6 \%$.

Terdapat perbedaan antara frekuensi miksi dan defekasi dengan penurunana berat badan neonatus, tetapi tidak terdapat perbedaan antara frekuensi minum dengan penurunan berat badan neonatus di wilayah kerja Puskesmas Banda Sakti.

\section{REFERENSI}

1. Gallacher DJ, Hart K, Kotecha S. Common Respiratory Conditions Of The Newborn. Breathe. 2016 Mar;12(1):30.

2. Dorland WN. Kamus Kedokteran Dorland. 31st ed. Mahode AlA, Arafn A, Intansarai DM, Fitra R, editors. Jakarta: EGC; 2010.

3. Chawla D, Agarwal R, Deorari AK, Paul VK. Fluid And Electrolyte Management In Term And Preterm Neonates. Indian J Pediatr. 2008 Mar;75(3):255-9.

4. Mezzacappa MA, Ferreira BG. Excessive Weight Loss In Exclusively Breastfed Full 
Term Newborns In A Baby Friendly Hospital. Rev Paul Pediatr. 2016 Sep;34(3):2816.

5. Ikatan Dokter Anak Indonesia. Buku Ajar Nutrisi Pediatrik Dan Penyakit Metabolik. 1st ed. Sjarif DR, Lestari ED, Mexitalia M, Nasar SS, editors. Jakarta: Badan Penerbit IDAI; 2011. 24 p.

6. Bertini G, Breschi R, Dani C. Physiological Weight Loss Chart Helps To Identify High Risk Infants Who Need Breastfeeding Support. Acta Paediatr. 2015 Oct;104(10):10247.

7. Jochum F, Moltu SJ, Senterre T, Nomayo A, Goulet O, Iacobelli S, et al. Guidelines On Pediatric Parenteral Nutrition: Fluid And Electrolytes. Clin Nutr. 2018;1-10.

8. Ambalavanan N. Fluid, Electrolyte, And Nutrition Management Of The Newborn. Nimavat DJ, editor. Pediatrics. 2018;

9. Joshi R, John B, Negi V. Pattern Of Weight Loss In Breastfed Neonates In Initial $72 \mathrm{H}$ Of Life. J Clin Neonatol. 2017;6(2):85.

10. Blackburn ST. Maternal, Fetal, Neonatal Physiology. 5th ed. louis, missouri: Elsevier Inc.; 2018. 378 p.

11. Ringer S. Fluid and Electrolyte Therapy in Newborns. Abrams S, Mattoo TK, Kim MS, editors. 2019

12. Ikatan Dokter Anak Indonesia. Perawatan Bayi Baru Lahir. IDAI. 2014

13. Tehuteru ES, Hegar B, Firmansyah A. Pola Defekasi Pada Anak. Sari Pediatr. 2016 Dec 6;3(3):129.

14. Safitri EE, Rokhanawati D. Perbandingan Laju Pertumbuhan Berat Badan Berdasarkan Jenis Konsumsi Susu pada Bayi Umur 6 Bulan di Puskesmas Mantrijeron Yogyakarta. 2012 Nov 17

15. Flaherman VJ, Schaefer EW, Kuzniewicz MW, Li SX, Walsh EM, Paul IM. Early Weight Loss Nomograms For Exclusively Breastfed Newborns. Pediatrics. 2015 Jan 135(1):e16-23.

16. Thulier D. Challenging Expected Patterns of Weight Loss in Full-Term Breastfeeding Neonates Born by Cesarean. JOGNN - J Obstet Gynecol Neonatal Nurs. 2017 Jan $1 ; 46(1): 18-28$.

17. Joshi R, John B, Negi V. Pattern of weight loss in breastfed neonates in initial $72 \mathrm{~h}$ of life. J Clin Neonatol. 2017;6(2):85.

18. Guerra L, Leonard M, Castagnetti M. Best practice in the assessment of bladder function in infants. Ther Adv Urol. 2014;6(4):148-64.

19. Wen J, Wang Q, Zhang X. Normal Voiding Pattern and Bladder Dysfunction in Infants and Children. Life Sci J. 2007;4(4):1097-8135.

20. Tran A, Fortier C, Giovannini-chami L, Demonchy D, Caci H. Evaluation of the Bladder Stimulation Technique to Collect Midstream Urine in Infants In a Pediatric Emergency Department. PLoS One. 2016;3:1-13.

21. Gladh G, Persson D, Mattsson S, Lindström S. Voiding Pattern in Healthy Newborns. Neurourol Urodyn. 2000 Jan 1;19(2):177-84.

22. Kleinman, Goulet, Vargani M, Sanderson, Sherman, Shneider. Walker's Pediatric Gastrointestinal Disease: Physiology, Diagnosis, Management. 6th ed. USA: PMPH USA; 1988

23. Cunningham CL, Banez GA. Pediatric Gastrointestinal Disorders: Biopsychosocial Assessment and Treatment. New York: Springer; 2006

24. Kimura RE, Warshaw JB. Metabolic Adaptations Of The Fetus And Newborn. J Pediatr Gastroenterol Nutr. 1983;2:S12-5.

25. Benjasuwantep B, Ruangdaraganon N. Bowel movements of normal Thai infants. Southeast Asian J Trop Med Public Health. 2009 May;40(3):530-7. 
26. Elbakyan A. Newborn: First Stool and Urine. Pediatr Rev. 1994 Aug 1;15(8):319-20.

27. Weaver LT, Ewing G, Taylor LC. The bowel habit of milk-fed infants. J Pediatr Gastroenterol Nutr. 1988;7(4):568-71.

28. Roesli Dr. Utami. mengenal ASI eksklusif. yani sudaro, editor. jakarta: trubus ageiwidya; 2005.

29. Dina AA. Hubungan Jenis Persalinan Dengan Waktu Pengeluaran Kolostrum Pada Pada Ibu Bersalin Kala IV Di Kota Yogyakarta Tahun2016. Politeknik Kesehatan Kemenkes Yogyakarta; 2016.

30. Herrera-Gómez A, García-Martínez O, Ramos-Torrecillas J, De Luna-Bertos E, Ruiz C, Ocaña-Peinado FM. Retrospective Study Of The Association Between Epidural Analgesia During Labour And Complications For The Newborn. Midwifery. 2015 Jun $1 ; 31(6): 613-6$.

31. Baskara L. Onset Laktasi Pada Bedah Sesar. Yogyakarta: Medika Salemba; 2015.

32. Saraung MW, Rompas S, Bataha YB. Analisis Faktor-Faktor Yang Berhubungan Dengan Produksi ASI Pada Ibu Pospartum Di Puskesmas Ranotana Weru. e-jurnal keperawatan. 2017;5(2).

33. Susanto H, Wilar R, Lestari H. Faktor - Faktor Yang Mempengaruhi Pemberian Susu Formula Pada Bayi Yang Dirawat Di Ruang Nifas Rsup Prof. Dr. R. D. Kandou Manado. e-CliniC. 2015;3(1).

34. Rahmiwati A. Karakteristik Pemberian Susu Formula Pada Bayi Usia Bawah Dua Tahun. J Keperawatan Sriwij. 2015;3(2355):11-8.

35. Noel-Weiss J, Woodend AK, Peterson WE, Gibb W, Groll DL. An Observational Study Of Associations Among Maternal Fluids During Parturition, Neonatal Output, And Breastfed Newborn Weight Loss. Int Breastfeed J. 2011 Aug 15;6(1):9.

36. Lamp JM, Macke JK. Relationships Among Intrapartum Maternal Fluid Intake, Birth Type, Neonatal Output, And Neonatal Weight Loss During The First 48 Hours After Birth. JOGNN - J Obstet Gynecol Neonatal Nurs. 2010 Mar 1;39(2):169-77.

37. Mulder PJ, Johnson TS, Baker LC. Excessive Weight Loss In Breastfed Infants During The Postpartum Hospitalization. JOGNN - J Obstet Gynecol Neonatal Nurs. 2010;39(1):15-26.

38. Lemoh JN, Brooke OG. Frequency and Weight of Normal Stools In Infancy. Aortography Infant coarctation. 1979;1:719-20.

39. Haseli A, Eghdampour F, Mozafari M, Hasani M, Ghiasi A, Masomi F. Associated factors with neonatalweight loss after birth. J Compr Pediatr. 2017;8(4).

40. Susanti R, Hasanah O, Utami GT. Perbandingan Kenaikan Berat Badan BBLR Yang Diberi Asi Dan Susu Formula Pada Dua Munggu Pertama Perawatan. 2014;(36):1-8.

41. Soetjiningsih. Hubungan Antara Frekuensi Menyusui Dan Status Gizi Ibu Menyusui Dengan Kenaikan Berat Badan Bayi 1-6 Bulan Di Puskesmas Alalak Sekta Banjarmasin Utara. Universitas Muhammadiyah Malang; 2016.

42. Gultom DA. Hubungan Pemberian ASI Eksklusif Terhadap Peningkatan Berat Badan Bayi Baru Lahir 0-14 Hari Di Rumah Bersalin Sari Medan Teladan Tahun2017. Poltekkes Kemenkes Medan; 2018.

43. Stan C. Standard For Infant Formula And Formulas For Special Medical Purposes Intended For Infants. 2016;

44. Yusuf M. Gambaran Pemberian Susu Formula Pada Bayi Usia 7-11 Bulan Di Wilayah Kerja Puskesmas Minasa Upa Tahun 2011. 2011; 